\title{
Factors Influencing Farmers' Adoption of Best Management Practices: A Review and Synthesis
}

\author{
Tingting Liu $1, *(\mathbb{D})$, Randall J. F. Bruins ${ }^{2}$ and Matthew T. Heberling ${ }^{3}$ \\ 1 National Drought Mitigation Center, University of Nebraska-Lincoln, Lincoln, NE 68583-0988, USA \\ 2 Ecosystems Integrity Branch, Systems Exposure Division, National Exposure Research Laboratory, \\ U.S. Environmental Protection Agency, Cincinnati, OH 45268, USA; randybruins@gmail.com \\ 3 Watershed Management Branch, National Risk Management Research Laboratory, \\ U.S. Environmental Protection Agency, Cincinnati, OH 45268, USA; Heberling.Matt@epa.gov \\ * Correspondence: gnuliutingting@gmail.com or tliu19@unl.edu
}

Received: 11 December 2017; Accepted: 30 January 2018; Published: 7 February 2018

\begin{abstract}
Best management practices (BMPs) for reducing agricultural non-point source pollution are widely available. However, agriculture remains a major global contributor to degradation of waters because farmers often do not adopt BMPs. To improve water quality, it is necessary to understand the factors that influence BMP adoption by farmers. We review the findings of BMP adoption studies from both developed and developing countries, published after (or otherwise not included in) two major literature reviews from 2007 and 2008. We summarize the study locations, scales, and BMPs studied; the analytical methods used; the factors evaluated; and the directionality of each factor's influence on BMP adoption. We then present a conceptual framework for BMP adoption decisions that emphasizes the importance of scale, the tailoring or targeting of information and incentives, and the importance of expected farm profits. We suggest that future research directions should focus on study scale, on measuring and modeling of adoption as a continuous process, and on incorporation of social norms and uncertainty into decision-making. More research is needed on uses of social media and market recognition approaches (such as certificate schemes and consumer labeling) to influence BMP adoption.
\end{abstract}

Keywords: conservation; best management practices; agriculture; water quality; nonpoint source pollution; policy

\section{Introduction}

Poor water quality, and in particular excess nitrogen $(\mathrm{N})$ and phosphorus loadings, is an international problem for reasons that include human population growth, the expansion of industrial and agricultural activities, and climate change [1,2]. In the United States (US), through the Clean Water Act and the National Pollutant Discharge Elimination System (NPDES) permit program, efforts have been made to control water pollution by regulating point sources that discharge pollutants to US waters [3]. Unlike nutrient pollution from point sources (including wastewater treatment facilities (WWTFs)), nonpoint source (NPS) pollution such as agricultural runoff is not directly regulated under the Clean Water Act and continues to be a major water pollution concern [1]. The 2000 National Water Quality Inventory found that agricultural NPS pollution was the leading source of water quality impacts in US lakes and rivers [4].

Although similar data are often difficult to obtain, studies elsewhere have shown that pollution from agriculture is also a major problem in many other developed and developing countries including the Netherlands, New Zealand, and China [5-7]. Recent events such as harmful algal blooms impacting drinking water have made this more recognizable [8]. Although many efforts have been made, outside of 
regulation, to control agricultural runoff, few policies have been successful $[9,10]$. Better understanding of the factors that influence farmers' conservation behavior is critical to changing this result.

Reducing nutrient pollution from agriculture remains challenging due to the large number of producers and the spatially variable and temporally dynamic nature of the nutrient loading process. Improvements will depend on better understanding of the nutrient loadings associated with various agricultural practices and land uses, as well as better understanding of flow regimes, loading processes, and water system interactions with land and climate [11]. Scientists and policy makers have emphasized the importance of targeting improvement efforts to the sources of greatest loading [12-14]. Numerous studies have also demonstrated the cost-effectiveness of targeting by practice and land use type [15-18]. However, farmers make the final decisions to adopt conservation practices or best management practices (BMPs) (henceforth, BMPs will include conservation practices which only usually refer to land retirement or no-tillage [19]). To make all conservation efforts more cost-effective and more readily adaptable, understanding the factors that influence farmers' adoption of BMPs is fundamental.

Approaches and tools that have been explored to achieve environmental benefits include voluntary programs, command-and-control regulations, and economic instruments such as input tax, ambient tax/subsidy, government financial assistance, water quality trading, liability rules and performance bonds [20]. However, we suggest that a better understanding of farmers' conservation adoption behaviors, including a comprehensive study of the factors that influence farmers' BMP adoption, is needed to inform the formulation and implementation of these approaches.

A recent workshop organized by US federal agencies on the role played by agriculture in global $\mathrm{N}$ pollution highlighted the need for additional research on grower adoption of BMPs. According to the workshop summary [21], "the appropriate technologies and basic knowledge for effectively mitigating reactive agricultural $\mathrm{N}$ loss already exist, but excess loadings of reactive $\mathrm{N}$ to the atmosphere and water continue, "due mostly to the lack of adoption of BMPs and appropriate technologies" (emphasis added). The report stresses the need for new and comprehensive practice adoption studies to be carried out that address a changing incentives landscape. Factors that may be influencing farmer adoption of BMPs in the current era include: increasing numbers of tenant farmers; smaller conservation budgets; impacts of social media on communications; introduction of certification schemes and consumer labeling; and increasing risks due to climate change. However, the summary also states that, "the financial motivations behind land manager decisions remain paramount and must therefore be central to research on practice adoption".

This paper reviews previous efforts to identify factors that influence farmers' conservation behavior and highlights future research directions. Existing literature tends to fall into three categories: applied economic studies, agent-based models (ABMs), and literature reviews. Applied economic studies, most of which focus on factors motivating agricultural producers' BMP adoption, tend to address the farm level or micro-scale. ABMs focus on modeling of behavior, often by allowing agents (agricultural producers) to interact with each other. These models incorporate adaptation based on past experiences, which can capture the complexity of spatial dynamic interactions among agents and learning-by-doing of agents themselves [22-24]. To maintain a manageable scope for this paper, however, we have omitted studies using ABMs from this review.

The last category includes literature review papers and reports that summarize and synthesize the factors that influence BMP adoption [14,25-29]. Among them, Pannell et al. [28] have reviewed a range of personal, social, and economic factors as well as the characteristics of BMPs themselves and how they influence adoption by rural landholders in Australia. Knowler and Bradshaw [26] reviewed 31 empirical analyses from all over the world (1984-2002). Prokopy et al. [29] reviewed 55 studies conducted from 1982 to 2007 on farmers' BMP adoption in the US. Osmond et al. [12,30] summarized the Conservation Effects Assessment Project (CEAP), which includes 13 projects jointly funded by USDA's National Institute of Food and Agriculture (NIFA) and Natural Resources Conservation Service (NRCS). Some of these projects evaluate the effects of cropland and pastureland BMPs on 
spatial and temporal trends in water quality at the watershed scale and some investigate social and economic factors that influence implementation and maintenance of practices.

Economic concerns have been and continue to be the main drivers of BMP adoption, but the economic theory behind farmers' behavior is often ignored $[14,28]$. Most models are at the micro scale, where researchers often assume individual farmers are economically rational and maximize profits (an assumption which incidentally ignores the possible influence on profits of farmer risk aversion). A farmer presumably compares all potential profits from alternative practices and then makes a decision about adoption. This helps explain why conservation practices are most often under-provided, since their benefits accrue to society [31]. When farmers adopt more than would be economically rational, other motivations besides profit maximization need to be considered; theories such as bounded rationality, non-rationality, and a rich body of psychological theory can help inform behavior [32].

Our paper is motivated by two objectives. First, we want to update the list of factors that helps explain farmer adoption of BMPs (post-2008 following Knowler and Bradshaw [26] and Prokopy et al. [29]) and identify research gaps. Next, we develop a conceptual framework that reflects these factors. To proceed, we discuss the scope of our review including study areas, scale and methods. We then summarize the factors and present our findings and future research areas.

\section{Scope of This Review}

\subsection{Literature Search}

We used a comprehensive approach including peer-reviewed articles, working papers, project reports, fact sheets, extension newsletters, and public presentations from both developed and developing countries to synthesize a broad review. The literature was collected from 1982 through early 2016 via the USDA NIFA Research, Education, and Economics Information System (REEIS) database, Web of science, and Google scholar, but we focus on more recent studies (2008 and later). The key words used were: conservation practices, best management practices, farmers, adoption, implementation and adaptation. We reviewed 121 peer reviewed papers, 21 book chapters, 15 reports, seven working papers, and seven CEAP fact sheets. Among the 121 peer reviewed papers, 100 are empirical studies, and 21 are literature reviews papers. Prior to characterizing the factors and developing the conceptual framework, we first consider the study locations, scale, and research methods.

\subsection{Geographic Locations}

Research on the factors influencing BMP adoption throughout the world has included both developed and developing countries $[27,33,34]$. The majority of case studies we reviewed were in the US and Australia, others were in Africa, Europe, South America, Asia and Canada. Different regions have different research emphases depending on the environmental concerns (Tables 1 and 2). For example, research in Australia and New Zealand tends to examine soil erosion and water retention issues [35], whereas European countries examine agricultural intensification, multifunctional agriculture, and sustainability [36-39]. Developing countries focus more on poverty issues and financial incentives for BMP adoption [27,34].

Similarly, within the US, issues vary by region. Generally, water quality issues associated with agricultural runoff are the biggest concern. Numerous studies in the Midwest (Corn Belt) and Mid-Atlantic regions focus on water quality because of impacts on the Gulf of Mexico and Chesapeake Bay $[14,40,41]$. However, in the California Bay Delta and Columbia River basin, research addresses water conservation, water quality improvement, and wildlife habitat restoration [42]. In the Prairie Grasslands Region, priorities focus on the protection and restoration of native grasslands and wetlands [42]. 


\subsection{Geographic Extent}

Most of the studies examine factors influencing farmers' BMP adoption at the micro level, focusing on farmer characteristics such as age, education, and experience. Few have worked at larger scales such as county or state, even though conservation benefits and outcomes cannot be realized without accounting for watershed-scale topography, soils, water resources, hydrology, and conservation practice adoption $[13,30,43]$. Among the eight USDA CEAP projects that conducted economic analyses such as tradeoffs between economic objectives and conservation objectives, only one project focused on the watershed [44]. In another watershed study, Newburn and Woodward [45] evaluated the economic and institutional aspects of the Great Miami River Water Quality Trading Program (a point-nonpoint trading program in Ohio) such as cost effectiveness, efficiency of bidding for agricultural BMPs, transaction costs, and innovation.

Research in watershed biophysical process models suggests that desired environmental outcomes may require a critical mass of factors to adopt BMPs before those benefits can be realized [46]. Additionally, there may be some unobserved variables at these larger scales that influence farmer behavior, such as local policies, the relationship between extension specialists, special programs staff and farmers, as well as specialists' expertise [45]. Other macro-scale factors such as policies, laws, markets, and state political views toward environmental severity (i.e., proportion of state waterways listed by the US Environmental Protection Agency as impaired) were also found to influence participation rates [46,47]. Thus, macro-scale variables can have a quick and dramatic impact on farmers' attitudes or behaviors toward BMPs. These factors can be critical for the design and implementation of policies intended to motivate conservation by farmers. Unlike the popular micro-level research that focuses on the individual farmer, a macro-level study requires the aggregation of many decisions. To our knowledge, Stuart and Gillon [48] is one of the few macro-level studies of conservation practice adoption; they used California and Iowa as examples to emphasize of the importance of scaling up. Reimer et al. [46] explored state-level decision-making using aggregated individual conservation decisions to estimate the factors influencing state-level Environmental Quality Incentive Program (EQIP) application decisions.

\subsection{Research Methods}

Existing research on factors influencing farmer adoption of BMPs includes literature reviews and original empirical studies. Literature review papers can synthesize recent efforts using different analytic approaches and identify gaps for future research. Empirical approaches used to model conservation program enrollment or conservation practice adoption include:

- Non-parametric approaches (e.g., correlation analysis, mean comparison and cluster analysis)

- $\quad$ Regression modeling

$>$ Ordinary least squares with application or enrollment rate as a continuous dependent variable;

$>$ Dichotomous models (logit, probit, and tobit) with adoption (adoption or not) or different stages of adoption (no adoption, early adoption and late adoption) as discrete dependent variables;

$>$ Duration analysis (survival model) to model the timing of adoption;

$>\quad$ Bayesian models; and

$>$ Spatial models to model the spatial integration of adoption among farmers and examine neighbors' influence.

Tables 1 and 2 summarize recent literature reviews and empirical papers on factors influencing farmers' BMPs, respectively. 
Table 1. Overview of literature review papers on factors influencing conservation practices or BMPs adoption.

\begin{tabular}{|c|c|c|c|c|}
\hline Source & Location/Extent & Data & Method & Conservation Practices \\
\hline Rubas [49] & Global & 170 studies from 32 countries & Meta-analysis & Agricultural production technologies \\
\hline Emtage et al. [50] & Australia & * & Descriptive & Natural Resource Management Programs \\
\hline Kabii and Horwitz [51] & Global & * & Descriptive & Conservation easement (or covenanting) programs \\
\hline Pannell et al. [28] & Global & * & Descriptive & Conservation practices \\
\hline Knowler and Bradshaw [26] & Global & 31 empirical analyses (1984-2002) & Vote count & $\begin{array}{l}\text { Conservation agriculture (soil conservation practices) } \\
\text { BMPs were defined as the actual implementation of }\end{array}$ \\
\hline Prokopy et al. [29] & US & $\begin{array}{l}55 \text { studies from } 25 \text { years } \\
\text { of literature }\end{array}$ & Vote count & $\begin{array}{c}\text { a practice that could be expected to lead to improved } \\
\text { water quality-not something that needs done in order to } \\
\text { implement a BMP }\end{array}$ \\
\hline Ahnström et al. [33] & Global & Literature up to Spring of $2005^{*}$ & Descriptive & Conservation practices in general \\
\hline Blackstock et al. [52] & Global & * & Descriptive & BMPs in general \\
\hline Lahmar [39] & $\begin{array}{l}\text { Global KASSA project ( } 28 \text { partners } \\
\text { from } 18 \text { countries in Europe, North } \\
\text { Africa, South-East Asia and Latin } \\
\text { America) }\end{array}$ & * & Descriptive & Conservation agriculture \\
\hline Llewellyn et al. [53] & Global & * & Descriptive with case studies & $\begin{array}{c}\text { Conservation practices } \\
\text { Conservation Reserve Program (CRP), cover crops, }\end{array}$ \\
\hline Tomer and Locke [54] & US & USDA CEAP & Descriptive & $\begin{array}{l}\text { livestock nutrient/pasture management, reduced or } \\
\text { no-tillage, riparian practices, nitrogen fertilizer rate and } \\
\text { timing, sediment control structures }\end{array}$ \\
\hline Baumgart-Getz et al. [25] & US & 46 studies from 1982 to 2007 & Meta-analysis & BMPs in general \\
\hline American Farmland Trust [55] & Global & * & Descriptive & Conservation practices \\
\hline Stuart and Gillon [48] & US & * & Descriptive with case studies & Conservation programs \\
\hline Burton [56] & Global & 53 papers & Descriptive and vote count & $\begin{array}{l}\text { Environmental behavior in general (focus on the farmer } \\
\text { demographic characteristics) }\end{array}$ \\
\hline Daloğlu et al. [57] & Global & * & Descriptive & Conservation practices \\
\hline Lesch and Wachenheim [58] & Global & * & Descriptive & $\begin{array}{c}\text { Tillage practices, riparian buffers and forest, technology } \\
\text { adoption, conservation reserve enhancement program } \\
\text { (CREP), Environmental Quality Incentives Program } \\
\text { (EQIP) }\end{array}$ \\
\hline Rode et al. [59] & Global & 18 empirical studies & Descriptive & $\begin{array}{l}\text { Conservation in general (focus on the economics } \\
\text { incentives of crowding in and crowing out) }\end{array}$ \\
\hline Wachenheim et al. [60] & Global & * & Descriptive & Conservation Reserve Program (CRP) \\
\hline Weber and McCann [61] & Global with case studies & * & Descriptive & $\begin{array}{l}\text { Best management practices, nitrogen-efficient plant } \\
\text { varieties, precision agriculture, and other } \\
\text { eco-innovations }\end{array}$ \\
\hline Woods et al. [62] & US & 13 cropland watershed-scale studies & Descriptive & $\begin{array}{l}\text { Conservation tillage (no-till), terraces, grassed } \\
\text { waterways, irrigation management, nutrient } \\
\text { management, riparian buffers and stream fencing }\end{array}$ \\
\hline
\end{tabular}

${ }^{*}$ Number of studies is not clear. 
Table 2. Overview of selected empirical papers on factors influencing conservation practices or BMP adoption.

\begin{tabular}{|c|c|c|c|c|}
\hline Authors & Study Area & Scale & Empirical Models & Conservation Practices or Programs \\
\hline Welch and Marc-Aurele [63] & $\begin{array}{c}\text { Skaneateles Lake Watershed, NY } \\
\text { (representative of New York's Finger Lakes) }\end{array}$ & Farm & Multinomial probit model & $\begin{array}{c}\text { Skaneateles Lake Watershed Agricultural Program (SLWAP). } \\
\text { No specific practices }\end{array}$ \\
\hline Cooper [64] & $\begin{array}{l}4 \text { critical watershed regions in US } \\
\text { (unspecified) }\end{array}$ & Farm & Multinomial probit model & $\begin{array}{l}\text { Conservation tillage, integrated pest management, legume } \\
\text { crediting, manure testing, soil moisture testing }\end{array}$ \\
\hline D’Emden et al. [65] & Southern Australia (1983-2003) & Farm & Survival model & Soil-conserving practices \\
\hline Parker et al. [66] & Sugar Creek Watershed, Ohio & Farm & Correlation analysis & $\begin{array}{l}\text { Conservation tillage, nutrient management, reduced fertilizer, } \\
\text { waste disposal, regular soil testing }\end{array}$ \\
\hline D’Emden et al. [67] & Australia & Farm & Logit model & Conservation tillage (no-till) \\
\hline Kara et al. [68] & US (19 highest corn producing states) & Farm & Multivariate probit model & $\begin{array}{l}\text { Conservation tillage, yield monitors, grassed waterways, } \\
\text { commercial fertilizer, manure management, erosion plan, soil } \\
\text { nutrient test, filter strips }\end{array}$ \\
\hline Lubell and Fulton [69] & California's Sacramento River Watershed & Farm & Ordered probit model & $\begin{array}{c}\text { Conventional pest management, alternative pest management, } \\
\text { and runoff controls }\end{array}$ \\
\hline Tiwari et al. [70] & Central Nepal & Farm & Logit model & $\begin{array}{l}\text { Improved conservation technology (improved terraces, hedge } \\
\text { plantation, construction of check dams and terrace bunds) }\end{array}$ \\
\hline Lamba et al. [71] & Southern Ontario, Canada & Farm & Correlation analysis & $\begin{array}{l}\text { Buffer strips, no-till, grass waterways, manure management, } \\
\text { forested riparian zones, wetlands, and erosion control }\end{array}$ \\
\hline Tosakana et al. [72] & Northern Idaho and eastern Washington & Farm & Ordered probit model & Gully plug and buffer strip \\
\hline Armstrong et al. [73] & Cannonsville Watershed, New York City, US & Farm & Logit model & Conservation Reserve Enhancement Program (CREP) \\
\hline Murage et al. [74] & West Kenya & Farm & Survival model & Crop protection \\
\hline Raymond and Brown [75] & La Moine River Watershed in western Illinois & Farm & Cluster analysis & $\begin{array}{c}\text { Grass waterways, no-tillage practices, reduced tillage practices, } \\
\text { cover crops, vegetated buffers }\end{array}$ \\
\hline Tamini [76] & Québec, Canada & Farm & Non-parametric approach & $\begin{array}{c}\text { Manure analysis, conservation tillage, immediate incorporation, } \\
\text { riparian buffer, non-use of mineral fertilizer, and hydraulic } \\
\text { infrastructures }\end{array}$ \\
\hline Gedikoglu and McCann [77] & Iowa and Missouri & Farm & Univariate probit model & $\begin{array}{l}\text { Growing Roundup Ready soybeans, manure testing, } \\
\text { Calibrating manure spreaders, maintaining setback between } \\
\text { streams and lakes and manure application areas }\end{array}$ \\
\hline Liu [78] & Four provinces in China & Farm & Survival model & Agricultural biotechnology \\
\hline Reimer et al. [46] & 50 States in US & State & Fractional logit model & Environmental Quality Incentives Program (EQIP) \\
\hline Savage and Ribaudo [10] & Chesapeake Bay Watershed & Farm & Logit and OLS & Comprehensive Nutrient Management Plans (CNMP) \\
\hline Haghjou et al. [79] & Iran & Farm & Ordered logit & Soil conservation practices \\
\hline Jacobson [80] & US & Farm & OLS and probit model & Conservation Reserve Program (CRP) \\
\hline Läpple and Hennessy [81] & Ireland & Farm & Multinomial logit model & Extension program \\
\hline Pannell et al. [27] & $\begin{array}{l}\text { Literature review in developing countries } \\
\text { and a case study in Zimbabwe }\end{array}$ & Farm & Simulation model & Rotation, zero tillage, zero tillage with mulching \\
\hline Wollni and Andersson [82] & La Paz, Honduras & Farm & $\begin{array}{c}\text { Bayesian spatial autoregressive } \\
\text { probit model }\end{array}$ & Organic farming \\
\hline Fleming et al. [83] & Maryland, US & Farm & Probit and multivariate tobit & Cover crop, contour-strip farming, no-till \\
\hline
\end{tabular}


Table 2. Cont.

\begin{tabular}{|c|c|c|c|c|}
\hline Howley et al. [84] & Ireland & Farm & Logit and ordered logit model & Land use change decision (afforestation) \\
\hline Thompson [85] & $\begin{array}{c}\text { South Australian Murray-Darling Basin, } \\
\text { Australia }\end{array}$ & Farm & Correlation analysis & Native vegetation conservation \\
\hline Kondylis et al. [86] & Mozambique & Farm & Linear probability model & sustainable land management techniques \\
\hline Turinawe et al. [87] & Southwestern Uganda & Farm & Logit model & $\begin{array}{l}\text { Soil and water conservation technologies (mulching, trash lines, } \\
\text { fallowing, manure and compost, trenches/diversion channels, } \\
\text { terraces, contour ploughing, grass strips, intercropping, crop } \\
\text { rotation, cover crops, tree planting and agroforestry) }\end{array}$ \\
\hline Ward et al. [88] & Malawi & Farm & Conditional logit model & $\begin{array}{c}\text { Conservation agriculture including intercropping, zero tillage, } \\
\text { and residue mulching }\end{array}$ \\
\hline Zhong et al. [89] & Kentucky River Watershed & Farm & Logit model & $\begin{array}{l}\text { Riparian buffers, fencing off animals, no-till, waste storage } \\
\text { facility, nutrient management }\end{array}$ \\
\hline Chouinard et al. [9] & Eastern Washington State, US & Farm & OLS & Conservation practices \\
\hline Ulrich-Schad et al. [90] & Indiana, US & Farm & Logit model & Conservation practices \\
\hline
\end{tabular}




\section{Findings: Factors Influencing BMP Adoption}

We compiled the results of studies published since the reviews of Knowler and Bradshaw [26] and Prokopy et al. [29]; we also include papers published before 2008 but not cited by these reviews. We then compared our findings with the results of Knowler and Bradshaw [26] and Prokopy et al. [29]. Besides a great deal of research being done on similar factors, progress has been made on other factors which have not been examined before, such as the influence of social norms and peer pressure [82,91,92]; the role of the macro factors, such as geographic regions, policies, markets and business; and macro-driven uncertainty and risks [27,44,67,93,94]. Farmers' time preference in conservation behavior was examined for the first time [27]. Recent research also shows the critical role that the characteristics of the BMPs, as well as the interactions among these practices, play in agricultural producers' decision making, which has been neglected in the literature $[17,95,96]$.

More attention is now being paid to information and awareness, and specifically to the importance of information sources. Farmers' risk aversion and environmental attitudes are receiving greater focus compared to a decade ago, but there is still room to better understand farmers' perception and attitudes in their conservation behavior [97-100].

In addition, we summarized different types of financial incentives/disincentives and interactions among BMPs that have been neglected in the literature $[80,82,87]$. Factors shown to influence conservation adoption, and areas in which research is lacking, are listed in Table 3 and outlined in the following sections. 
Table 3. Summary of findings on factors influencing BMP adoption by farmers. For details (e.g., locations and caveats), see text. Effect symbols are defined at end of table.

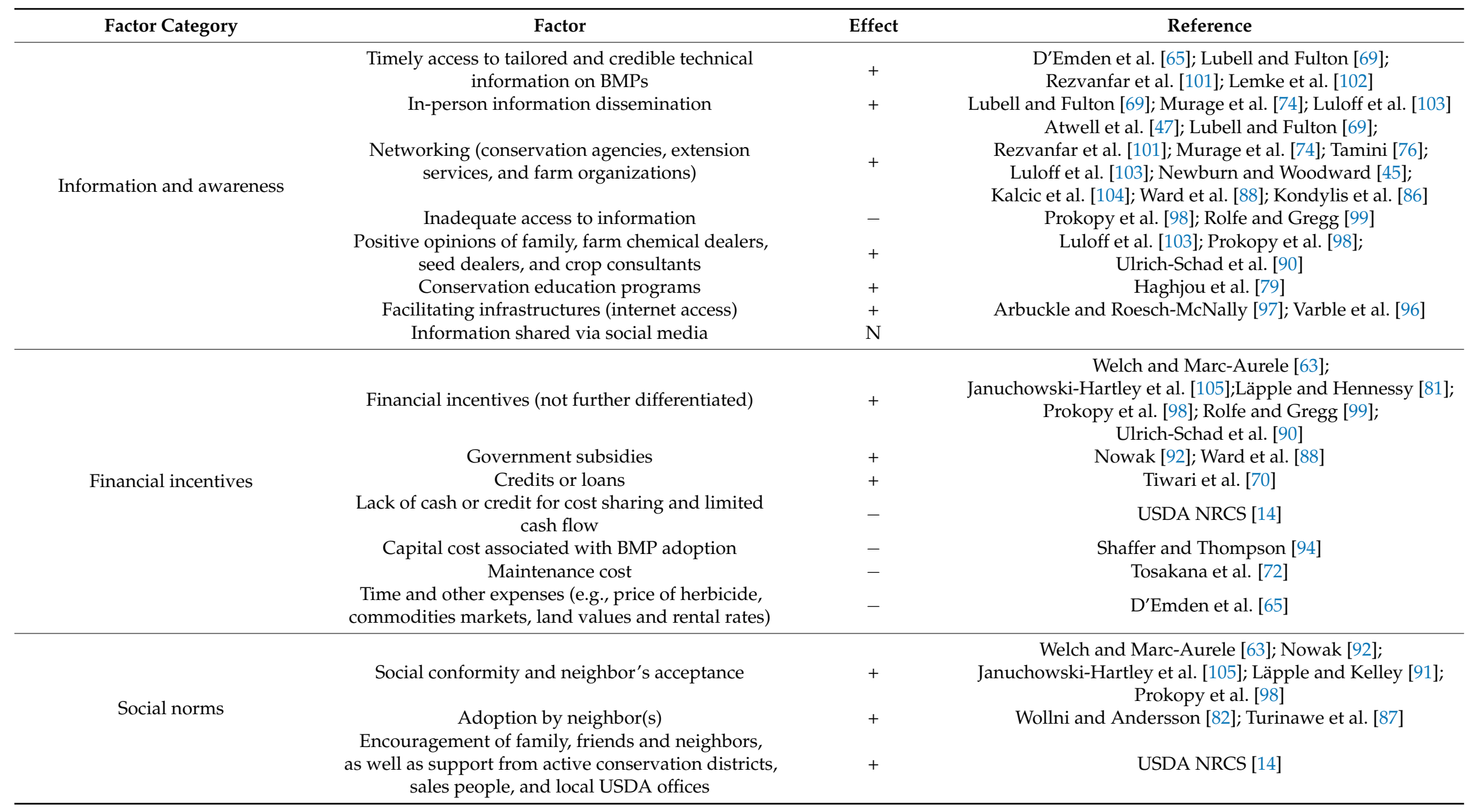


Table 3. Cont.

\begin{tabular}{|c|c|c|c|}
\hline Macro factors & $\begin{array}{c}\text { Geographic regions } \\
\text { Share of agricultural production in total GDP of } \\
\text { a state } \\
\text { Climate change and extreme weather conditions } \\
\text { Uncertainties regarding market price and } \\
\text { conservation regulations } \\
\text { Roles of policies, markets, business or agencies }\end{array}$ & $\begin{array}{c}+/- \\
+ \\
\mathrm{N} \\
- \\
\mathrm{U}\end{array}$ & $\begin{array}{c}\text { Cox [106]; Arbuckle [93]; Shaffer and Thompson [94]; } \\
\text { Pannell et al. [27] } \\
\text { D’Emden et al. [67]; Raymond and Brown [75] }\end{array}$ \\
\hline \multirow{4}{*}{$\begin{array}{l}\text { Farmers' demographics, } \\
\text { knowledge, and attitudes }\end{array}$} & $\begin{array}{c}\text { Age } \\
\text { Gender (being female) } \\
\text { Income and capital, and level of gross farm sales }\end{array}$ & $\begin{array}{l}+/ \mathrm{U} \\
+/ \mathrm{U} \\
+\end{array}$ & $\begin{array}{c}\text { Tiwari et al. [70]; Chouinard et al. [9] } \\
\text { Tiwari et al. [70]; Druschke and Secchi [107]; Ward et al. [88] } \\
\text { Kara et al. [68]; Tiwari et al. [70]; Lamba et al. [71]; } \\
\text { Gedikoglu and McCann [77] }\end{array}$ \\
\hline & $\begin{array}{l}\text { Lifestyle (or hobby) } \\
\text { The household life stage, history of family ownership } \\
\text { of a landholding, family size and structure }\end{array}$ & $\begin{array}{l}- \\
\mathrm{U}\end{array}$ & $\begin{array}{l}\text { Greiner et al. [108] } \\
\text { Salamon et al. [109] }\end{array}$ \\
\hline & $\begin{array}{l}\text { Family member planning to take over the farm } \\
\text { Higher caste }\end{array}$ & $\begin{array}{l}+ \\
+\end{array}$ & $\begin{array}{c}\text { Ahnström et al. [33] } \\
\text { Tiwari et al. [70] }\end{array}$ \\
\hline & $\begin{array}{c}\text { Farmers' experience and education } \\
\text { Political views and sociopolitical beliefs }\end{array}$ & $\begin{array}{c}+/ \mathrm{U} /- \\
\mathrm{U}\end{array}$ & $\begin{array}{l}\text { Lamba et al. [71]; Gedikoglu and McCann [77]; } \\
\text { Haghjou et al. [79]; Ward et al. [88]; Chouinard et al. [9] } \\
\text { Januchowski-Hartley et al. [105]; Ulrich-Schad et al. [90] }\end{array}$ \\
\hline \multirow{4}{*}{$\begin{array}{l}\text { Farmers' risk and time preferences } \\
\text { and uncertainty }\end{array}$} & Risk averse & - & $\begin{array}{c}\text { Sheriff ([110]; Brandt and Baird [111];Nyaupane and } \\
\text { Gillespie [112]; Teklewold and Kohlin [113]; Liu [78]; } \\
\text { Pannell et al. [27]; Prokopy et al. [98]; Arbuckle and } \\
\text { Roesch-McNally [97]; Rolfe and Gregg [99]; Vignola et al. } \\
\text { [100] }\end{array}$ \\
\hline & Conservation risks tolerance & + & Chouinard et al. [9] \\
\hline & Positive time preference & + & Liebenehm and Waibel; Pannell et al. [27] \\
\hline & $\begin{array}{l}\text { Uncertainties with the installation and adaptation and } \\
\text { management skills }\end{array}$ & - & USDA NRCS [14] \\
\hline $\begin{array}{l}\text { Farmer's environmental } \\
\text { consciousness }\end{array}$ & $\begin{array}{l}\text { Awareness of water quality, soil erosion, and impact } \\
\text { of BMPs on the environment } \\
\text { Environmental stewardship or steward intentions }\end{array}$ & $\begin{array}{l}+ \\
+\end{array}$ & $\begin{array}{c}\text { Lubell and Fulton [69]; Gedikoglu and McCann [77]; } \\
\text { Haghjou et al. [79]; Ulrich-Schad et al. [90] } \\
\text { Tiwari et al. [70]; Chouinard et al. [9] }\end{array}$ \\
\hline
\end{tabular}


Table 3. Cont.

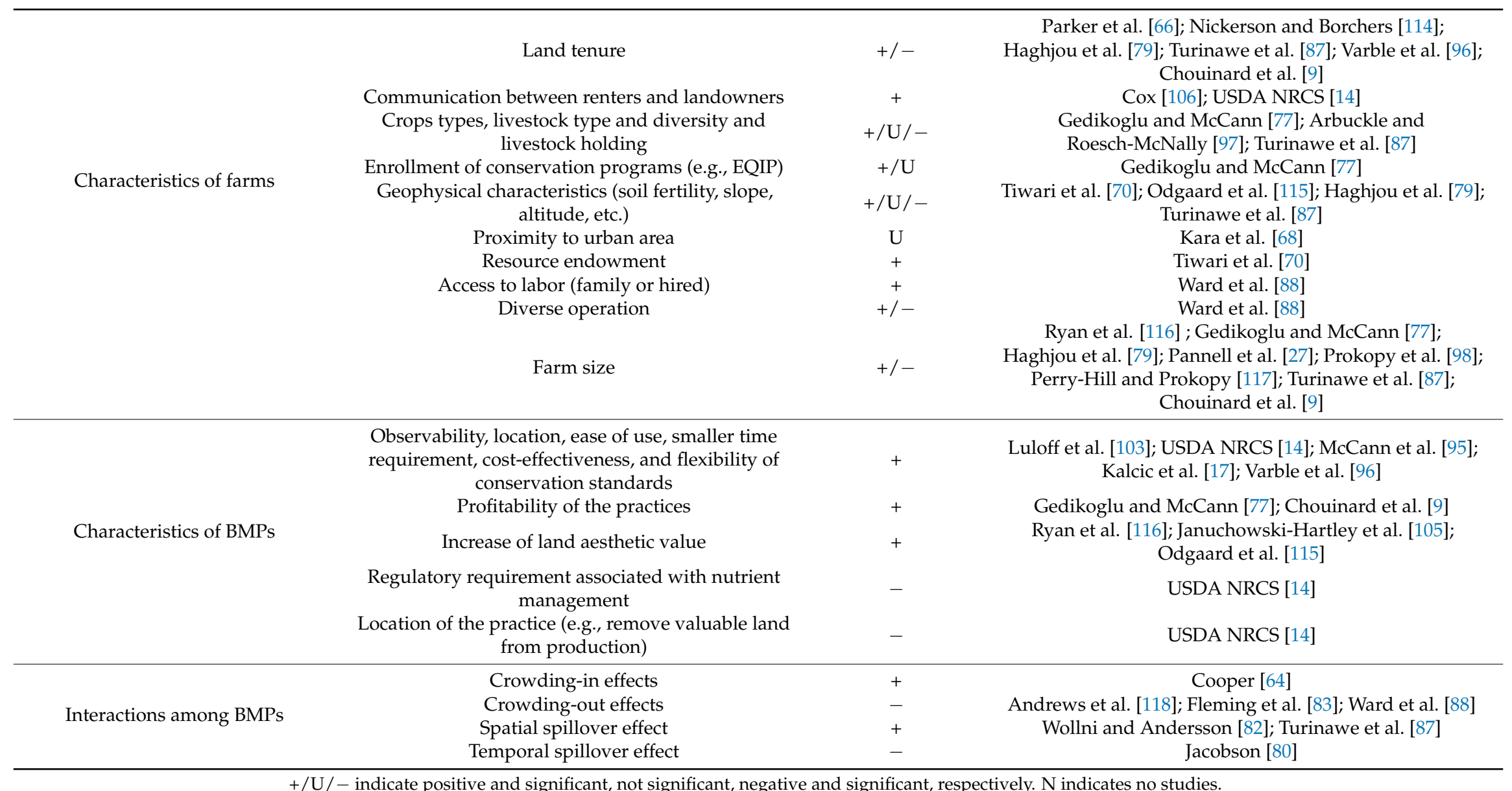




\subsection{Information and Awareness of BMPs}

Timely access to information on conservation programs or on specific BMPs can be critical for adoption. For example, D'Emden et al. [65] ascertained that the availability and use of technical information are important in the adoption of an erosion-reducing cropping system in southern Australia. However, smaller and non-traditional farmers might not have access to adequate conservation information and outreach and may not get the tools or training necessary to adopt better practices $[98,99]$.

Information sources matter in farmers' decision-making. Building on the Prokopy et al. [29] finding that networking (including agency, business, and local) was a significant predictor of BMP adoption, more recent studies show that conservation education can be improved by encouraging more interpersonal contact between conservation agencies and farmers, and the need for farmer-to-farmer communication $[69,79,103]$. In addition, other key stakeholders such as fertilizer dealers and their affiliated certified crop advisors were ascertained to be influential $[55,98,103]$. Llewellyn [53] reviewed empirical studies to identify factors influencing no-till adoption and extension targets in Australia. He found that conservation education training is the primary tool available to effect practice change. Extension services provide timely and effective information on practices as well as new technologies $[76,88,101,102]$, and proximity to extension agents increases adoption [101]. Atwell et al. [47], Kalcic et al. [104] and Woods et al. [62] found that interactions with local conservation staff frequently are positively correlated with adoption. Newburn and Woodward [45] did an ex post evaluation of Ohio's Great Miami Water Quality Trading Program and showed that the reliance on trusted agents from county-level Soil and Water Conservation District offices to recruit and advise farmers was essential to achieving relatively high rates of farmer participation. Lubell and Fulton [69] further demonstrated that exposure to conservation networks (such as contacting conservation agencies, participating in watershed management meetings, reading brochures, taking training classes, etc.) substantially increases the probability of adopting BMPs. In another study, Prokopy et al. [98] surveyed 4778 medium- to large-sized corn producers. They also found that family, farm chemical dealers, seed dealers, and crop consultants are the key sources of information influencing a farmer's agricultural practices and strategy adoption. Kondylis et al. [86] ran a large-scale field experiment in Mozambique to examine the role of gender in dissemination of sustainable land management techniques and found female farmers were more likely to learn and adopt the technique through female messengers.

We only identified one study that evaluated the effectiveness of different dissemination pathways. Murage et al. [74] compared seven dissemination pathways for their impact on farmers' adoption of the "push-pull" technology in Western Kenya, while controlling the effects of selected socio-economic and regional factors. The seven dissemination pathways included public meetings, radio, farmer field schools, field days or open day demonstrations, farmer teachers or trainers, print materials and fellow farmers (farmer to farmer extension). Findings indicated the use of field days was the quickest way to communicate technological information, followed by farmer-teachers. Mass media plays an important role in the awareness of BMPs and their potential impact on the environment; however, research on the impact of social media, particularly internet-based social networks, is missing. Internet and technology advances, particularly in mobile devices, enable information access at a very low cost compared to traditional media such as radio, TV, newspapers and magazines. Varble et al. [96] found that renters (including both tenants and part-owners) and owners use different sources for information, and farmers who rely on the internet for conservation information may be more advanced in their use of technologies and might be considered adoption leaders. Facilitating factors such as technological infrastructures can support BMP adoption [97]. Popular social media (e.g., Facebook, Twitter and YouTube) offer many opportunities to get conservation and BMP information without time and location constraints, although the quality of the information may vary. Research is needed to analyze access to social media and its role in informing farmer decisions. 


\subsection{External Incentives/Disincentives Acting on Farmer Motivation and Perceptions}

\subsubsection{Financial Incentives}

There is a vast literature on the role of financial incentives in motivating BMP adoption, and its findings are consistent with the economic rational assumption that financial incentives can encourage BMP adoption [57,63,81,99,105]. More specifically, government subsidies [88,92,119] and credits or loans [70] were found to be positively correlated with adoption of BMPs. Prokopy et al. [98] surveyed farmers in the Eagle Creek watershed of Central Indiana and found that all farmers interviewed were motivated by financial gain, albeit to various degrees. Welch and Marc-Aurele [63] also found early adopters more motivated by financial incentives, and that whereas wealthy or resource abundant farmers may be more likely to adopt BMPs with a regulatory push, resource-poor farmers or farmers who receive most of their income from farming may be better motivated by financial tools. Läpple and Hennessy [81] explored the role of financial incentives in agricultural extension programs among Irish farmers and found that financial incentives encourage participation, especially with cohorts of farmers that previously eschewed such programs. Conversely, USDA NRCS [14] found that one of the barriers to conservation program enrollment is financial, including a lack of cash or credit for cost sharing and limited cash flow while waiting for government reimbursement.

Associated costs, including opportunity costs, play important roles in the adoption decision-making process. For example, capital costs associated with BMP adoption have been regarded as the primary barrier for producers in California [94]. For practices such as gully plugs and buffer strips, the financial stress and the cost of structure implementation were less important than maintenance costs [72]. D'Emden et al. [65] investigated possible trade-offs faced by farmers where adoption of no-till cropping technology can lead to greater herbicide reliance with subsequent unsustainable weed management due to herbicide resistance. The price of the herbicide glyphosate was identified to be one of the determinants of the timing of no-till adoption.

\subsubsection{Social Norms and Peer Pressure}

Social norms and peer pressure may have great impacts on agricultural producers' perceptions and attitudes and play key roles in the adoption process [29]. If a well-respected farmer in the community has success with a practice, then other farmers will follow, leading to rapid diffusion through the community. In addition, encouragement of family, friends and neighbors, as well as support from active conservation districts, sales people, and local USDA offices, make BMP adoption more likely [14]. The economic intuition is straightforward that farmers may derive increased utility from social conformity and make their adoption decision contingent on their neighbors' acceptance [91].

Due to the technical difficulty of measuring social norms or peer pressure, combined with the challenge of explaining the spatial patterns of BMP adoption, few empirical papers have examined the importance of these factors on agricultural producers' decision-making until recently. Wollni and Andersson [82], after studying the spatial patterns of organic agriculture adoption in Honduras, found that neighborhood effects exist such that farmers are more likely to convert to organic farming if their neighbors are also adopters. Turinawe et al. [87] also found that use of soil and water conservation technologies in neighbors' parcels increases the probability of adoption by $45 \%$, if everything else is fixed.

Social conformity concerns also matter. Better access to accurate information, either directly or through their neighborhood network, make farmer groups more likely to adopt organic agriculture. However, Wollni and Andersson [82] found that farmers who perceive that their adoption decision would provide free benefits to nearby plots are less likely to adopt. Welch and Marc-Aurele [63] similarly found that late adopters are more pressured by the community and their peers, where early adopters are more driven by financial incentives and regulation. In another example, Nowak [92] found that, whereas early BMP adopters were more motivated by payment, late adopters were more influenced by early adopters and their neighbors. 


\subsubsection{Macro Factors Such as Location, Climate and Policy Instruments}

Macro-scale factors play an increasingly important role in shaping agricultural producer decision-making regarding environmental stewardship. Concerns about climate change and extreme weather conditions may exacerbate farmer reluctance, and the crop market price, as well as conservation regulation, also influences the adoption of BMPs. However, these are rarely investigated [44,93]. D'Emden et al. [67] and Reimer et al. [46] examined adoptions in Australia and the US respectively and found significant difference among regions. D'Emden et al. [67] suggested agroecological factors such as soil types, rainfall distribution, and soil fertility may influence the adoption decision. Reimer et al. [46] suggested other macro-scale factors such as state-wide political views may have an influence on conservation program participation, whereas the effect of government agencies and the role of individual political opinion were less clear. Reimer et al. [119] found that the states with a population more opposed to public environmental spending are more likely to have higher EQIP application rates. Kara et al. [68] found that share of agricultural production in total Gross Domestic Product (GDP) of a state has a positive and significant impact on BMP adoption. Stuart and Gillon [48] (2013) illustrated scenarios where policy and market changes have led to a significant loss of participation in conservation efforts. More specifically, landowners or agricultural producers in Iowa quickly responded to the increasing price of corn by choosing not to re-enroll in conservation programs when contracts expired or to terminate contracts early and repay all contract income plus interest. Some farmers were reluctant to enroll in conservation programs, worrying about the inconsistency of the programs.

\subsection{Characteristics of Farmers}

\subsubsection{Demographics, Knowledge, and Attitudes}

Consistent with studies reviewed earlier by Prokopy et al. [29], which found that farmers who adopted BMPs tend to have more income and capital, more diverse operations, better access to labor and a higher level of gross farm sales, recent studies also found that income, capital and level of gross farm sales have a positive impact [68,70,71,77], as did higher caste [70], and family members planning to take over the farm [33]. Emtage et al. [50] and Greiner et al. [108] found that farmers who value conservation and "lifestyle" more than financial and social incentives have higher adoption rates of BMPs than others within the same industry and region. Lifestyle farmers or "lifestylers" are retired professionals, hobby farmers, or absentee farmers [50]. In Greiner et al. [108], farms with less than US $\$ 100,000$ in annual sales are often lifestyle farms or hobby farms where farm income is not the major/sole source of income.

However, recent studies found mixed results for farmers' age, experience, education, and gender [56,71,77,79]. For example, Rahelizatovo and Gillespie [120] found that younger dairy producers tended to adopt BMPs more than older producers in Louisiana, whereas Tiwari et al. [70] ascertained that age did not play a significant role in the adoption of improved soil conservation technology in Nepal. Being female may increase the probability of adoption in some developing countries where females are in charge of farming [88], but not others [70]. Druschke and Secchi [107] found that females had significantly lower levels of knowledge about BMPs but significantly more positive attitudes toward BMPs and collaboration than men. Additionally, the history of family ownership of a landholding, family size and structure, and household life stage may matter as well [50,109].

Recent studies also show the importance of understanding the impact of political views and sociopolitical beliefs on BMP adoption [46,105]. Reimer et al. [46] found that state political views have influence on EQIP program participation rates, though not in the expected direction. Januchowski-Hartley et al. [105] examined the participation of riverine restoration by linking social factors to the expected benefits that landholders would anticipate from participation. 


\subsubsection{Risk and Time Preferences and Uncertainty}

Agricultural producers' risk and time preferences are also factors in BMP adoption $[9,97,99,112,113]$. After capital costs, the risk of a loss of crop yield constituted the second most significant barrier to BMP adoption identified by California specialty crop growers [94]. Farmers' willingness to take on the risks that come with BMP adoption is an important consideration because there are uncertainties with the installation, especially in their adaptation to heterogeneous fields. Farmers may worry that the BMP will reduce crop yields or that they lack the skills needed for BMP success [14]. Sheriff [110] found that farmers tend to over-apply nutrients to address the risk of spring field entry, risk of wet conditions, and variable uptake of nutrients based on year-to-year changes. Brandt and Baird [111] highlighted corn farmers' concerns of yield and income risks when adopting water quality BMPs. Prokopy et al. [98] used no-till corn in Indiana as an example to show that farmers are risk-averse. At the time of their study, about $22 \%$ of Indiana fields used no-till practices, due to farmers' concerns for the possibility of reduced yield. Liu [78] found that cotton farmers who are more risk averse and more loss averse adopt technology later. Vignola et al. [100] similarly found smallholder farmers in developing countries to be risk-averse due to their low education levels, low income, and poor access to technical assistance, market and credits. Pannell et al. [27] are among the very few studies that we found that accounted for planning horizons and discount rate when investigating new technologies and BMP adoptions.

Although uncertainty and risk are important in agricultural producers' decision-making, they are rarely investigated in the literature because of the complexities of estimation. Pannell et al. [27] is one of the few studies that illustrate the potential impacts of risk and uncertainty using scenario analysis. They find that larger and better-resourced farms have potential economic gains after BMP adoptions in Northern Zimbabwe, compared to resource-poor smallholders, in particular, are likely to be highly risk-averse. They also find that the effect of uncertainty is unambiguously negative for conservation practices.

\subsubsection{Farmer's Environmental Consciousness}

Environmental consciousness is believed to have a positive impact on farmers' BMP adoption. Many studies have included environmental consciousness variables, such as awareness of water quality, soil erosion, and impact of BMPs on the environment, and have found that awareness often leads to adoption of BMPs $[69,77,79,119]$. Being an environmental steward or having steward intentions $[9,70]$ also have positive impacts on BMP adoption. However, assessment of this impact can be complicated by heterogeneity among farmers with regard to their willingness to support rural conservation planning priorities [85]. After an extensive review of existing indices to measure farmers' environmental attitudes, Thompson et al. [85] designed a new index to better measure the heterogeneity. Tosakana et al. [72] identified the importance of changing farmers' perceptions of the effectiveness of BMPs. Armstrong et al. [73] found that farmers' attitudes (e.g., resentment) toward land cost and conservation policy are a strong predictor of enrollment in the Conservation Reserve Enhancement Program in the New York City watershed.

\subsection{Characteristics of Farms}

Studies have examined the effects on BMP adoption of geophysical, sociopolitical and management characteristics of farms such as farm fertility $[79,87,115]$, slope $[9,87]$, altitude [70], proximity to urban area [68], communication between renters and landowners [14,106], conservation program enrollment [77], and diverse operation (i.e., diversity of crops and livestock [77,87,88,97]. Access to labor including family members or hired workers also increased BMP adoption [88]. Mixed results were found for diverse operation. Rahelizatovo and Gillespie [120] found diverse operation can increase the chances of BMP adoption among dairy producers in Louisiana; in Malawi, Ward et al. [88] found that ownership of grazing animals such as goats and sheep is associated with lower valuation of zero tillage, but did not affect valuation of mulching. 
Two other issues also are equivocal in the BMP-adoption literature [57]. The first is the importance of land tenure of farms. The common assumption is that renters operate on the land for a shorter period than the owner and thus are less likely to adopt practices which will benefit the environment or themselves over the long run. Many micro-level empirical studies of BMP adoption confirmed this expectation $[66,79,87,114]$. Parker et al. [66] studied Sugar Creek Watershed in Ohio and found strong evidence for positive relationships between farm succession, land tenure and BMP adoption. However, recent research has also shown some evidence that renters are more likely to adopt BMPs than landowners [46,96]. For example, Varble et al. [96] found that renters in Iowa's Clear Creek Watershed are more likely than owners to plant an intensive corn rotation, but they also practice conservation tillage at a higher rate than owners. The reason is the renters farmed more highly erodible land than the owners, but to comply with government regulations they tended to adopt conservation tillage. Reimer et al. [46] found that states with more tenant farmers show higher application rates for the EQIP program. Nevertheless, tenure security, along with investment security, communication between renters and landowners, cost-sharing and risk-sharing can facilitate conservation practice adoption $[14,106]$.

The second equivocal issue is farm size. Most studies have found that producers operating large farms are more likely to adopt BMPs, because they are more aware of environmental issues and BMPs, are willing to invest in new technology and have more resources to invest $[25,27,79,98]$. Small farms need more incentives due to the lack of resources or economies of scale in BMP implementation. For example, the adoption of no-till is not always an option for resource-poor farmers in South Asia and Africa because of the cost of herbicides [27]. Prokopy et al. [98] surveyed farmers in the Little Calumet-Galien watershed in Indiana, USA, and discovered smaller farms are less likely to adopt BMPs because operators were less aware of pollutants and BMPs and had less access to information to improve water quality and the environment. However, other researchers have shown that small scale growers are more positive towards improving the environment and are more motivated by non-economic incentives [116,117]. Some research suggested that there is no clear relationship between farm size and conservation [33].

\subsection{Characteristics of $B M P S$}

Characteristics of BMPs such as observability, location, ease of use, time requirement, cost-effectiveness, flexibility of conservation standards, relative advantage conferred to the farm can influence the adoption decision $[17,103]$. Readily observable practices, such as the use of terraces, grassed waterways, and conservation tillage to reduce soil erosion, are sometimes preferred over less-observable practices [14,95]. Farmers also like to engage in BMPs that increase land aesthetic value $[105,115,116]$. Nutrient management, riparian buffers and stream fencing are less preferred or disliked, because the benefits are not observable and the impacts on water quality take years or even decades to be noticed [54]. Some farmers did not like the regulatory requirements associated with nutrient management, and some did not trust the $\mathrm{N}$ application rate suggested by university extension staff [14]. Another important characteristic is the location of the practice. For example, farmers are less likely to adopt practices that remove valuable land from production. Farmers in several watersheds of Georgia, Kansas, and Ohio have negative feelings towards riparian buffers since they encumber the most valuable land on their farms [14]. Thus, the promotion of certain practices such as riparian buffers may require larger incentives. USDA NRCS [14] verified that stream fencing and creation of waste storage facilities are positively correlated with level of compensation.

\subsection{Interactions among BMPs, and Spatial and Temporal Spillover Effects}

Conservation practice benefits may interact with one another; thus, bundling different types of BMPs may make adoption more cost-effective. Cooper [64] considered BMPs as a bundle of interrelated practices and found that identifying and packaging BMPs that are perceived to be jointly beneficial can increase adoption and lower the costs of voluntary adoption programs. Rode et al. [59] 
reviewed 18 empirical studies and found that economic incentives can undermine (crowd out) or reinforce (crowd in) motivation to implement the intended BMPs, or different BMPs. Andrews [118] suggested the possibility of modest financial payments crowding out intrinsic motivations for contributions to public goods such as soil conservation. Fleming et al. [83] found both crowding out and crowding in exist among cover crop, conservation tillage, and contour-strip in nitrogen, phosphorous, and sediment abatement costs sharing programs. Ward et al. [88] have shown that increased adoption of intercropping and residue mulching may crowd out adoption of zero tillage as the farmers may focus on immediate benefits instead of the long-term benefits that zero tillage can provide.

Efforts have also been made to examine spatial spillover (i.e., the influence of BMP adoption on one's neighbors) or temporal spillover (i.e., the influence of adopting one practice on an individual's likelihood of subsequently adopting others) effects. Some of the benefits from BMPs can extend spatially to individuals other than the adopting producers [121]. For example, some soil BMPs may benefit farmers downstream by retaining soil and reducing erosion. Other research has focused on the spatial slippage that occurs when conservation programs increase productive farm land scarcity and some less productive land is brought into production temporarily [122-124]. Temporal spillover has been examined by studying the impact of adoption of certain BMPs (such as enrollment in a conservation program) on the later adoption of other practices (such as staying in the same conservation program or switching to another program) [80]. She finds that CRP leads to land being $20-25 \%$ more likely to be farmed, potentially offsetting some environmental benefits. However, former CRP land is slightly more likely to use a conservation practice.

\section{Conceptual Framework}

Researchers also have found that BMP adoption can be regarded as a temporally dynamic learning process having different stages $[14,121,125,126]$. In a typical sequence, farmers first become aware of available BMPs and their potential relevance to them [121]. The second stage is "interest," which often leads to collecting information about the practices, their applicability and their possibility of adoption. The third stage is "trial and evaluation." Most farmers test BMPs before widespread adoption because of the risk of failure; trial adoption and evaluation can reduce the risk and develop skills. The last stage is "adoption and adaptation." Based on trial results, the farmer then decides to scale up the adoption and to customize practices to their own fields. Most often this involves a lag, which again suggests treating BMP adoption as a continuous process [121].

Based on our findings, we have sought to construct an explicit conceptual diagram illustrating the factors influencing BMP adoption by farmers. Our starting point is a model developed by Greiner and Gregg [31], which showed motivation and perception of farmers and characteristics and constraints of farms as the two proximal determinants (Figure 1). Our diagram (Figure 2) maintains this basic distinction, but, by making scale (especially the down-scaling process) and the temporal progression of the adoption process more explicit, we emphasize the need for both researchers and policy-makers to grapple with their implications.

In accordance with recent findings, we place additional emphasis on scale, information provision, financial impact, and the role of policy makers and information providers. We distinguish the micro (farm) scale, at which adoption decisions are made, from the macro (watershed, regional or national) scale at which BMPs are designed, information is developed, and policies are implemented. This distinction helps to highlight the importance of tailoring or targeting as critical to the flow of information or policy from the macro to the micro scale, showing that when these aspects are deficient, adoption is less likely. Conservation policy-makers and information providers (for example, regulators, extension or education programs, crop consultants, seed and equipment dealers) take account of socioeconomic and biophysical conditions and make recommendations at macro scales. They may or may not engage in "downscaling" - that is, information provided to farmers (for example, nutrient application recommendations) can be tailored toward micro (farm or field) conditions, and incentives 
can be targeted as well to locations where they will be most cost-effective. Downscaling is challenging, however, and the extent to which it is accomplished varies greatly (as we indicate using dashed boxes), with trust in the information provider playing an important role.

Individual characteristics of farmers (including age, experience, education, risk preference, heritage, "lifestyle" and environmental consciousness) influence their awareness of and interest in BMPs, and ultimately their perceptions and decisions. Characteristics of farms (farm size, land tenure, type of production, and soils), along with farmer experience, are important determinants of expected farm income with the BMP, and any financial incentives provided. Based on these factors, a farmer's motivations, and their perceptions of uncertainty and risk, determine the initial adoption or enrollment decision, which may be done on a trial basis. Evaluation of the trial can lead to decisions regarding continuation or expansion on the part of the farmer and may further impact the farmer's neighbors. Accordingly, our framework shows the farmer decision process as subject to constant updating, as experience is gained and trial adoption is either expanded or abandoned. However, the temporal dimension of the adoption process is not well studied.

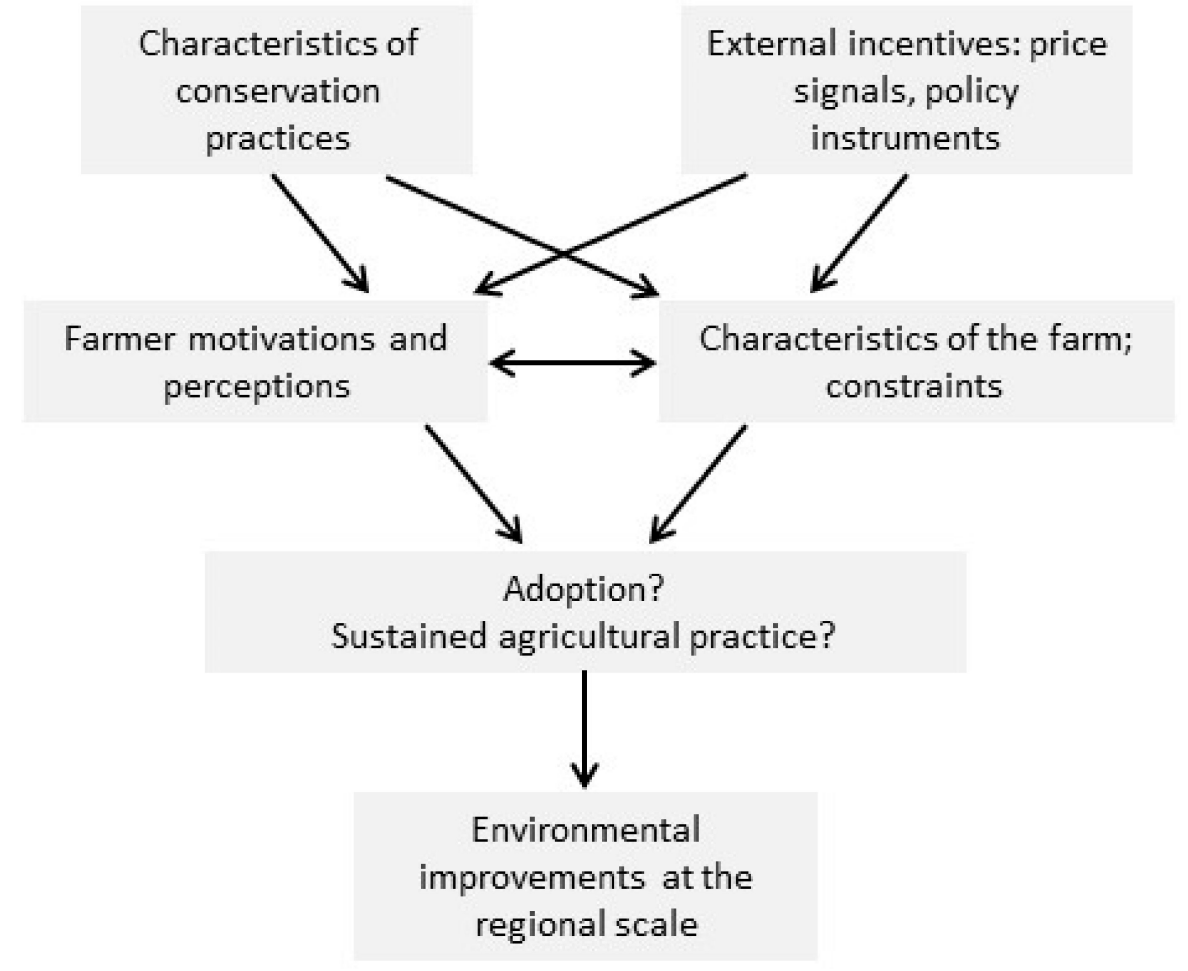

Figure 1. Greiner and Gregg's [31] conceptual framework of BMP adoption.

Our findings show that information is critical in conservation adoption. However, building the trust of farmers to use the various information sources can be important as well. We learned that different types of farmers are motivated by different strategies at different stages of adoption. Examining behavior at a large scale can be more effective, since the impacts of BMPs can be better realized after taking account of the complexity and nonlinear nature of watershed processes [14]. Other factors at the large scale, such as policies, markets, people, businesses, or agencies may also have a profound impact on adoption [44,48]. 


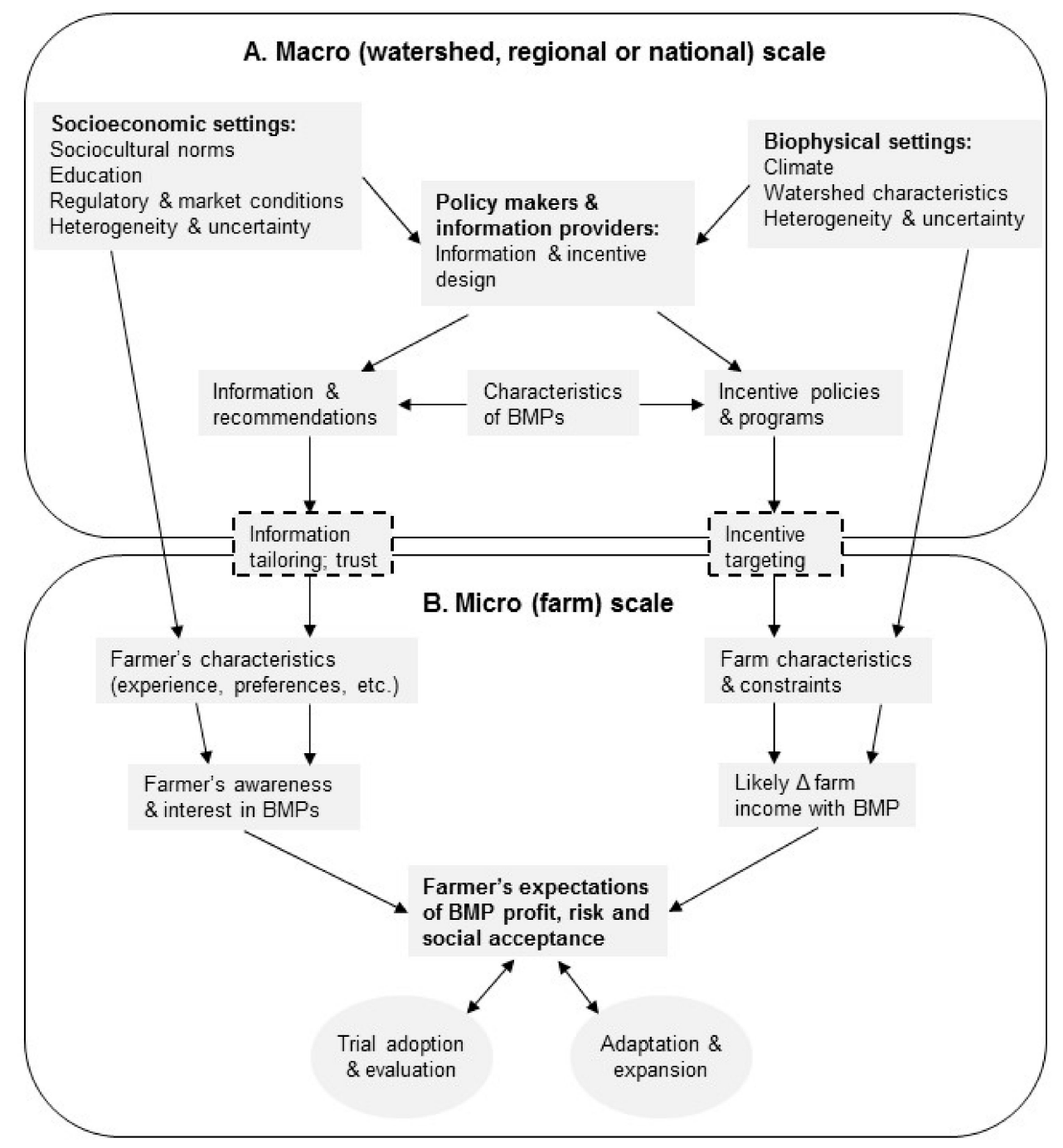

Figure 2. Revised conceptual framework of BMP adoption. Boxes and arrows denote influences; rounded boxes denote scales; ovals represent actions related to BMP adoption; dashed boxes denote elements that may or may not be present.

\section{Conclusions and Future Directions}

Our review has summarized a growing body of research on factors motivating the adoption of BMPs by farmers. Empirical research has focused on a wide range of factors such as information, profits (farm income and off-farm income), land tenure, farm size, experience, and education. Certain factors, studied in isolation, show a clear and positive effect on BMP adoption; these include access to credible information, government subsidies, environmental consciousness, and profitability of practices. The effects of some other factors, including farm size, land tenure, diverse operation, farmer experience, education, age, gender, political views, and social political beliefs, were unclear or debatable. We also find that further progress has been made to elucidate the roles of social norms and peer pressure and the influence of macro factors such as geographic regions, policies, markets, business, with their associated uncertainty and risks [26,29]. Farmers' time preference and characteristics of the BMPs, as well as the interactions among these practices, are examined for the first time in the literature. Additionally, more attention is now being paid to information, farmers' risk preference and farmers' environmental attitudes. Despite this increased attention, more progress is needed in these emerging areas of research. 
Given current research gaps and the complexities of the agricultural producer's decision-making process, we have presented a conceptual framework for factors affecting BMP adoption decisions (Figure 2) and we highlight some research areas to improve conservation adoption. We have recognized both micro and macro scales of influence on adoption decisions and we believe that, on balance, factors operating at larger scales need greater emphasis. As one example, research should address the role of market recognition in BMP adoption. Certification schemes and consumer labeling have been introduced in USDA NRCS since 2005, but the performances of these approaches for motivating conservation adoption have not been assessed. Social media also are believed to have great potential for the timely and inexpensive dissemination of information on conservation. More studies are needed to examine their impact on adoption decisions.

More research also is needed on the decision-making process itself. Many questions remain regarding the nuances of farmers' adoption behavior, such as preferences among practices or switching of practices. Better ways of measuring adoption may meet this need, including mathematical approaches to quantify various types and degrees of adoption, follow-up interviews or field visits from conservation personnel.

Since better understanding of farmers' environmental attitudes can be crucial in explaining conservation behavior, further investigation of agricultural producers' perception of environmental severity and the heterogeneity of attitudes among different groups would help in better understanding farmers' behaviors. Future efforts on time preference for BMP adoption is also needed since the factors motivating farmers' long-term adoption may be different from the short-term factors. For example, different conceptual models for renters and owners may be necessary since the time horizon for decision-making can be dramatically different. Even among tenured farmers, the planning horizon can vary. Thus, accounting for multiple planning lengths (5-year, 10-year, and 20-year) could be beneficial, and multiple discount rates could be used for representing the cost of the capital, the preference of farmers towards the profits, or both.

Future research can also incorporate social norms and risks into decision-making processes, theoretically and empirically. Direct examination of the impacts of social norms and peer pressure is also necessary; experiments or surveys, and incorporation of expertise from other fields, may help accomplish this. Because uncertainty surrounding BMPs can greatly influence farmers' decision-making, future efforts should use scenario analysis to explore how farmers respond to different regulations, the role of government agencies (federal, state, and local), and financial assistance programs under conditions of market price and weather fluctuations. Finally, while we excluded agent-based models from the scope of this review, we acknowledge that the use of such models holds promise for further clarifying the potential behavior of farmers in socially, spatially and temporally dynamic settings.

Acknowledgments: This project was supported in part by an appointment to the Research Participation Program at the Office of Research and Development (ORD), U.S. Environmental Protection Agency, administered by the Oak Ridge Institute for Science and Education through an interagency agreement between the U.S. Department of Energy and EPA. The views expressed in this article are those of the authors and do not necessarily reflect the views or policies of the U.S. Environmental Protection Agency. Any mention of trade names or commercial products does not constitute endorsement or recommendation for use.

Author Contributions: Tingting Liu collected and compiled the literature; Tingting Liu, Randall J.F. Bruins and Matthew T. Heberling designed the structure of the literature review paper, analyzed, synthesized and wrote the paper.

Conflicts of Interest: The authors declare no conflict of interest.

\section{References}

1. United Nations Department of Economic and Social Affairs (UNDESA). International Decade for Action 'Water for Life' 2005-2015. 2014. Available online: http: / /www.ais.unwater.org/water-for-life-decadereport/ Water-for-Life-DecadeReport_WEB.pdf (accessed on 2 February 2018). 
2. United States Environmental Protection Agency. Climate Change and Nutrient Interaction. US EPA water research. 2015. Available online: http://www2.epa.gov/water-research/climate-change-and-nutrientinteraction (accessed on 2 February 2018).

3. United States Environmental Protection Agency. NPDES Permit Writers' Manual. 2010. Available online: https:/ / www.epa.gov/sites/production/files/2015-09/documents/pwm_2010.pdf (accessed on 2 February 2018).

4. United States Environmental Protection Agency National Water Quality Inventory 2000 Report. 2002. Available online: https: / / www.epa.gov/sites / production/files/2015-09/documents /2000_national_water_ quality_inventory_report_to_congress.pdf (accessed on 2 February 2018).

5. Heggie, K.; Savage, C. Nitrogen yields from New Zealand coastal catchments to receiving estuaries. N.Z. J. Mar. Freshwater Res. 2009, 43, 1039-1052. [CrossRef]

6. Ongley, E.D. Control of Water Pollution from Agriculture-FAO Irrigation and Drainage Paper 55; Food and Agriculture Organization of the United Nations: Rome, Italy; GEMS/Water Collaboration Centre Canada Centre for Inland Waters: Burlington, ON, Canada, 1996.

7. Ongley, E.D.; Xiaolan, Z.; Tao, Y. Current status of agricultural and rural non-point source pollution assessment in China. Environ. Pollut. 2010, 158, 1159-1168. [CrossRef] [PubMed]

8. McCarty, J. USDA Commits \$5 Million to Help Farmers Reduce Runoff Feeding Lake Erie Toxic Algae Bloom. Available online: http:/ / www.cleveland.com/metro/index.ssf/2015/08/usda_responds_to_plea_from_ bro.html (accessed on 2 February 2018).

9. Chouinard, H.H.; Wandschneider, P.R.; Paterson, T. Inferences from sparse data: An integrated, meta-utility approach to conservation research. Ecol. Econ. 2016, 122, 71-78. [CrossRef]

10. Savage, J.; Ribaudo, M. Improving the Efficiency of Voluntary Water Quality Conservation Programs. Land Econ. 2016, 92, 148-166. [CrossRef]

11. U.S. Environmental Protection Agency (USEPA). Watershed Modeling to Assess the Sensitivity of Streamflow, Nutrient, and Sediment Loads to Potential Climate Change and Urban Development in 20 U.S. Watersheds; (Final Report), EPA/600/R-12/058F; U.S. Environmental Protection Agency: Washington, DC, USA, 2013.

12. Osmond, D.; Meals, D.; Hoag, D.; Arabi, M. How to Build Better Agricultural Conservation Programs to Protect Water Quality: The NIFA-CEAP Experience; Soil and Water Conservation Society: Ankeny, IA, USA, 2012.

13. Osmond, D.; Meals, D.; Hoag, D.; Arabi, M.; Luloff, A.; Jennings, G.; McFarland, M.; Spooner, J.; Sharpley, A.; Line, D. Improving conservation practices programming to protect water quality in agricultural watersheds: Lessons learned from the National Institute of Food and Agriculture-Conservation Effects Assessment Project. J. Soil Water Conserv. 2012, 67, 122A-127A. [CrossRef]

14. USDA NRCS. USDA NIFA Conservation Effects Assessment Project (CEAP) Fact Sheets. USDA NRCS NIFA. 2011. Available online: http:/ / www.soil.ncsu.edu/publications/NIFACEAP (accessed on 2 February 2018).

15. Arabi, M.; Govindaraju, R.S.; Hantush, M.M. Cost-effective allocation of watershed management practices using a genetic algorithm. Water Resour. Res. 2006, 42. [CrossRef]

16. Gitau, M.W.; Veith, T.L.; Gburek, W.J. Farm-level optimization of BMP placement for cost-effective pollution reduction. Trans. ASAE 2004, 47, 1923-1931. [CrossRef]

17. Kalcic, M.M.; Frankenberger, J.; Chaubey, I.; Prokopy, L.; Bowling, L. Adaptive Targeting: Engaging Farmers to Improve Targeting and Adoption of Agricultural Conservation Practices. J. Am. Water Resour. Assoc. 2015, 51, 973-991. [CrossRef]

18. Sample, D.J.; Heaney, J.P.; Wright, L.T.; Fan, C.-Y.; Lai, F.-H.; Field, R. Costs of best management practices and associated land for urban stormwater control. J. Water Res. Plan. Manag. 2003, 129, 59-68. [CrossRef]

19. Caswell, M.; Fuglie, K.; Ingram, C.; Jans, S.; Kascak, C. Adoption of Agricultural Production Practices; AER-792; Economic Research Service/USDA: Washington, DC, USA, 2001.

20. Dowd, B.M.; Press, D.; Los Huertos, M. Agricultural nonpoint source water pollution policy: The case of California's Central Coast. Agric. Ecosyst. Environ. 2008, 128, 151-161. [CrossRef]

21. USEPA-USDA-USGS. EPA-USDA-USGS Working Meeting on Management Strategies for Reactive Nitrogen and Co-Pollutants; Report from Meeting Held June 2014; U.S. Environmental Protection Agency: Washington, DC, USA, 2015.

22. LeBaron, B.; Tesfatsion, L. Modeling macroeconomies as open-ended dynamic systems of interacting agents. Am. Econ. Rev. 2008, 98, 246-250. [CrossRef] 
23. Tesfatsion, L. Agent-based computational economics: Growing economies from the bottom up. Artif. Life 2002, 8, 55-82. [CrossRef] [PubMed]

24. Tesfatsion, L. Elements of Dynamic Economic Modeling: Presentation and Analysis. East Econ. J. 2017, 43, 192-216. [CrossRef]

25. Baumgart-Getz, A.; Prokopy, L.S.; Floress, K. Why farmers adopt best management practice in the United States: A meta-analysis of the adoption literature. J. Environ. Manag. 2012, 96, 17-25. [CrossRef] [PubMed]

26. Knowler, D.; Bradshaw, B. Farmers' adoption of conservation agriculture: A review and synthesis of recent research. Food Policy 2007, 32, 25-48. [CrossRef]

27. Pannell, D.J.; Llewellyn, R.S.; Corbeels, M. The farm-level economics of conservation agriculture for resource-poor farmers. Agric. Ecosyst. Environ. 2014, 187, 52-64. [CrossRef]

28. Pannell, D.J.; Marshall, G.R.; Barr, N.; Curtis, A.; Vanclay, F.; Wilkinson, R. Understanding and promoting adoption of conservation practices by rural landholders. Aust. J. Exp. Agric. 2006, 46, 1407-1424. [CrossRef]

29. Prokopy, L.S.; Floress, K.; Klotthor-Weinkauf, D.; Baumgart-Getz, A. Determinants of agricultural best management practice adoption: Evidence from the literature. J. Soil Water Conserv. 2008, 63, 300-311. [CrossRef]

30. Osmond, D.; Meals, D.; Hoag, D.; Arabi, M.; Luloff, A.; McFarland, M.; Jennings, G.; Sharpley, A.; Spooner, J.; Line, D. Agriculture and Sustainable Practices: Protecting Water Quality. In Water Sustainability in Agriculture; NABC: Ithaca, NY, USA, 2015.

31. Greiner, R.; Gregg, D. Farmers' intrinsic motivations, barriers to the adoption of conservation practices and effectiveness of policy instruments: Empirical evidence from northern Australia. Land Use Policy 2011, 28, 257-265. [CrossRef]

32. Groeneveld, J.; Müller, B.; Buchmann, C.M.; Dressler, G.; Guo, C.; Hase, N.; Hoffmann, F.; John, F.; Klassert, C.; Lauf, T. Theoretical foundations of human decision-making in agent-based land use models-A review. Environ. Modell. Softw. 2017, 87, 39-48. [CrossRef]

33. Ahnström, J.; Hockert, J.; Bergea, H.L.; Francis, C.A.; Skelton, P.; Hallgren, L. Farmers and nature conservation: What is known about attitudes, context factors and actions affecting conservation? Renew. Agric. Food Syst. 2009, 24, 38-47. [CrossRef]

34. Andersson, J.A.; D'Souza, S. From adoption claims to understanding farmers and contexts: A literature review of Conservation Agriculture (CA) adoption among smallholder farmers in southern Africa. Agric. Ecosyst. Environ. 2014, 187, 116-132. [CrossRef]

35. Tranter, B. Political divisions over climate change and environmental issues in Australia. Environ. Polit. 2011, 20, 78-96. [CrossRef]

36. Brink, C.; van Ierland, E.; Hordijk, L.; Kroeze, C. Cost_effective emission abatement in agriculture in the presence of interrelations: cases for the Netherlands and Europe. Ecol. Econ. 2005, 53, 59-74. [CrossRef]

37. Huylenbroeck, G.V.; Durand, G. Multifunctional Agriculture: A New Paradigm for European Agriculture and Rural Development; Ashgate Publishing Ltd.: Farnham, UK; Burlington, VT, USA, 2003.

38. Jones, C.; Basch, G.; Baylis, A.; Bazzoni, D.; Biggs, J.; Bradbury, R.; Chaney, K.; Deeks, L.; Field, R.; Gomez, J. Conservation Agriculture in Europe: An Approach to Sustainable Crop Production by Protecting Soil and Water? SOWAP; Jealott's Hill International Research Center: Bracknell, UK, 2006.

39. Lahmar, R. Adoption of conservation agriculture in Europe: lessons of the KASSA project. Land Use Policy 2010, 27, 4-10. [CrossRef]

40. Kling, C.L. Economic incentives to improve water quality in agricultural landscapes: Some new variations on old ideas. Am. J. Agric. Econ. 2011, 93, 297-309. [CrossRef]

41. Wu, J.; Tanaka, K. Reducing nitrogen runoff from the upper Mississippi River basin to control hypoxia in the Gulf of Mexico: easements or taxes? Mar. Resour. Econ. 2005, 20, 121-144. [CrossRef]

42. USDA NRCS. Critical Conservation Areas. 2014. Available online: http://www.nrcs.usda.gov/wps/portal/ nrcs/detail/national/programs/farmbill/rcpp/?cid=stelprdb1254053 (accessed on 2 February 2018).

43. Tomer, M.; Sadler, E.; Lizotte, R.; Bryant, R.; Potter, T.; Moore, M.; Veith, T.; Baffaut, C.; Locke, M.; Walbridge, M. A decade of conservation effects assessment research by the USDA Agricultural Research Service: Progress overview and future outlook. J. Soil Water Conserv. 2014, 69, 365-373. [CrossRef]

44. Hoag, D.; Chaubey, I.; Popp, J.; Gitau, M.; Chang, L.; Pennington, J.; Rodríguez, H.; Gbur, E.; Nelson, M.; Sharpley, A. Lincoln Lake Watershed, Arkansas: National Institute of Food and Agriculture-Conservation 
Effects Assessment Project. In How to Build Better Agricultural Conservation Programs to Protect Water Quality; Soil and Water Conservation Society: Ankeny, IA, USA, 2012; pp. 171-200.

45. Newburn, D.A.; Woodward, R.T. An ex post evaluation of Ohio's Great Miami water quality trading program. J. Am. Water Resour. Assoc. 2012, 48, 156-169. [CrossRef]

46. Reimer, A.P.; Gramig, B.M.; Prokopy, L.S. Farmers and conservation programs: Explaining differences in Environmental Quality Incentives Program applications between states. J. Soil Water Conserv. 2013, 68, 110-119. [CrossRef]

47. Atwell, R.C.; Schulte, L.A.; Westphal, L.M. Linking resilience theory and diffusion of innovations theory to understand the potential for perennials in the US Corn Belt. Ecol. Soc. 2009, 14, 30. [CrossRef]

48. Stuart, D.; Gillon, S. Scaling up to address new challenges to conservation on US farmland. Land Use Policy 2013, 31, 223-236. [CrossRef]

49. Rubas, D. Technology Adoption: Who Is Likely to Adopt and How Does the Timing Affect the Benefits? Texas A \& M University: College Station, TX, USA, 2004.

50. Emtage, N.; Herbohn, J. Implications of landholders' management goals, use of information and trust of others for the adoption of recommended practices in the Wet Tropics region of Australia. Landsc. Urban Plan 2012, 107, 351-360. [CrossRef]

51. Kabii, T.; Horwitz, P. A review of landholder motivations and determinants for participation in conservation covenanting programmes. Environ. Conserv. 2006, 33, 11-20. [CrossRef]

52. Blackstock, K.L.; Ingram, J.; Burton, R.; Brown, K.M.; Slee, B. Understanding and influencing behaviour change by farmers to improve water quality. Sci. Total Environ. 2010, 408, 5631-5638. [CrossRef] [PubMed]

53. Llewellyn, R.S.; Vanclay, F.; Pannell, D. Identifying and targeting adoption drivers. In Changing Land Management: Adoption of New Practices by Rural Landholders; CSIRO Publishing: Clayton, VIC, Australia, 2011.

54. Tomer, M.; Locke, M. The challenge of documenting water quality benefits of conservation practices: a review of USDA-ARSs conservation effects assessment project watershed studies. Water Sci. Technol. 2011, 64, 300. [CrossRef] [PubMed]

55. American Farmland Trust. The Adoption of Conservation Practices in Agriculture. DeKalb, Illinois: The Adoption of Conservation Practices in Agriculture American Farmland Trust Center for Agriculture in the Environment. 2013. Available online: https:/ /4aa2dc132bb150caf1aa-7bb737f4349b47aa42dce777a72d5264.ssl.cf5.rackcdn.com/ Adoption-of-Conservation-Practices-in-Agriculture.pdf (accessed on 2 February 2018).

56. Burton, R.J. The influence of farmer demographic characteristics on environmental behaviour: A review. J. Environ. Manag. 2014, 135, 19-26. [CrossRef] [PubMed]

57. Daloğlu, I.; Nassauer, J.I.; Riolo, R.L.; Scavia, D. Development of a farmer typology of agricultural conservation behavior in the American Corn Belt. Agric. Syst. 2014, 129, 93-102. [CrossRef]

58. Lesch, W.C.; Wachenheim, C.J. Factors Influencing Conservation Practice Adoption in Agriculture: A Review of the Literature; North Dakota State University, Department of Agribusiness and Applied Economics: Fargo, ND, USA, 2014.

59. Rode, J.; Gómez-Baggethun, E.; Krause, T. Motivation crowding by economic incentives in conservation policy: A review of the empirical evidence. Ecol. Econ. 2014, 109, 80-92. [CrossRef]

60. Wachenheim, C.J.; Lesch, W.C.; Dhingra, N. The Conservation Reserve Program: A Literature Review; North Dakota State University, Department of Agribusiness and Applied Economics: Fargo, ND, USA, 2014.

61. Weber, C.; McCann, L. Adoption of Nitrogen-Efficient Technologies by US Corn Farmers. J. Environ. Qual. 2015, 44, 391-401. [CrossRef] [PubMed]

62. Woods, B.R.; Luloff, A.; Osmond, D.; Hoag, D. Toward a Synthesis: Lessons from Thirteen Cropland Watershed-Scale Studies. Soc. Nat. Resour. 2014, 27, 341-357. [CrossRef]

63. Welch, E.W.; Marc-Aurele, F.J., Jr. Determinants of farmer behavior: Adoption of and compliance with best management practices for nonpoint source pollution in the Skaneateles Lake watershed. Lake Reserv. Manag. 2001, 17, 233-245. [CrossRef]

64. Cooper, J.C. A joint framework for analysis of agri-environmental payment programs. Am. J. Agric. Econ. 2003, 85, 976-987. [CrossRef]

65. D'Emden, F.H.; Llewellyn, R.S.; Burton, M.P. Adoption of conservation tillage in Australian cropping regions: an application of duration analysis. Technol. Forecast Soc. Chang. 2006, 73, 630-647. [CrossRef] 
66. Parker, J.S.; Moore, R.; Weaver, M. Land tenure as a variable in community based watershed projects: some lessons from the Sugar Creek Watershed, Wayne and Holmes Counties, Ohio. Soc. Nat. Resour. 2007, 20, 815-833. [CrossRef]

67. D'Emden, F.H.; Llewellyn, R.S.; Burton, M.P. Factors influencing adoption of conservation tillage in Australian cropping regions. Aust. J. Agric. Resour. Econ. 2008, 52, 169-182. [CrossRef]

68. Kara, E.; Ribaudo, M.; Johansson, R.C. On how environmental stringency influences adoption of best management practices in agriculture. J. Environ. Manag. 2008, 88, 1530-1537. [CrossRef] [PubMed]

69. Lubell, M.; Fulton, A. Local policy networks and agricultural watershed management. J. Public Adm. Res. Theory 2008, 18, 673-696. [CrossRef]

70. Tiwari, K.R.; Sitaula, B.K.; Nyborg, I.L.; Paudel, G.S. Determinants of farmers' adoption of improved soil conservation technology in a middle mountain watershed of central Nepal. Environ. Manag. 2008, 42, 210-222. [CrossRef] [PubMed]

71. Lamba, P.; Filson, G.; Adekunle, B. Factors affecting the adoption of best management practices in southern Ontario. Environmentalist 2009, 29, 64-77. [CrossRef]

72. Tosakana, N.; Van Tassell, L.; Wulfhorst, J.; Boll, J.; Mahler, R.; Brooks, E.; Kane, S. Determinants of the adoption of conservation practices by farmers in the Northwest Wheat and Range Region. J. Soil Water Conserv. 2010, 65, 404-412. [CrossRef]

73. Armstrong, A.; Ling, E.J.; Stedman, R.; Kleinman, P. Adoption of the Conservation Reserve Enhancement Program in the New York City watershed: The role of farmer attitudes. J. Soil Water Conserv. 2011, 66, 337-344. [CrossRef]

74. Murage, A.W.; Obare, G.; Chianu, J.; Amudavi, D.M.; Pickett, J.; Khan, Z.R. Duration analysis of technology adoption effects of dissemination pathways: A case of 'push-pull' technology for control of striga weeds and stemborers in Western Kenya. Crop Prot. 2011, 30, 531-538. [CrossRef]

75. Raymond, C.M.; Brown, G. Assessing conservation opportunity on private land: Socio-economic, behavioral, and spatial dimensions. J. Environ. Manag. 2011, 92, 2513-2523. [CrossRef] [PubMed]

76. Tamini, L.D. A nonparametric analysis of the impact of agri-environmental advisory activities on best management practice adoption: A case study of Quebec. Ecol. Econ. 2011, 70, 1363-1374. [CrossRef]

77. Gedikoglu, H.; McCann, L.M. Adoption of win-win, environment-oriented, and profit-oriented practices among livestock farmers. J. Soil Water Conserv. 2012, 67, 218-227. [CrossRef]

78. Liu, E.M. Time to change what to sow: Risk preferences and technology adoption decisions of cotton farmers in China. Rev. Econ. Stat. 2013, 95, 1386-1403. [CrossRef]

79. Haghjou, M.; Hayati, B.; Momeni Choleki, D. Identification of factors affecting adoption of soil conservation practices by some rainfed farmers in Iran. J. Agric. Sci. Technol. 2014, 16, 957-967.

80. Jacobson, S. Temporal spillovers in land conservation. J. Econ. Behav. Organ. 2014, 107, 366-379. [CrossRef]

81. Läpple, D.; Hennessy, T. Assessing the Impact of Financial Incentives for Participation in Extension Programmes: Evidence from Ireland. In Proceedings of the 88th Annual Conference, Paris, France, 9-11 April 2014.

82. Wollni, M.; Andersson, C. Spatial patterns of organic agriculture adoption: Evidence from Honduras. Ecol. Econ. 2014, 97, 120-128. [CrossRef]

83. Fleming, P.; Lichtenberg, E.; Newburn, D.A. Agricultural Cost Sharing and Conservation Practices for Nutrient Reduction in the Chesapeake Bay Watershed. In Proceedings of the 2015 AAEA \& WAEA Joint Annual Meeting, San Francisco, CA, USA, 26-28 July 2015; Agricultural and Applied Economics Association \& Western Agricultural Economics Association: Milwaukee, WI, USA, 2015.

84. Howley, P.; Buckley, C.; Donoghue, C.O.; Ryan, M. Explaining the economic 'irrationality'of farmers' land use behaviour: The role of productivist attitudes and non-pecuniary benefits. Ecol. Econ. 2015, 109, $186-193$. [CrossRef]

85. Thompson, A.W.; Reimer, A.; Prokopy, L.S. Farmers' views of the environment: the influence of competing attitude frames on landscape conservation efforts. Agric. Hum. Values 2015, 32, 385-399. [CrossRef]

86. Kondylis, F.; Mueller, V.; Sheriff, G.; Zhu, S. Do female instructors reduce gender bias in diffusion of sustainable land management techniques? Experimental evidence from Mozambique. World Dev. 2016, 78, 436-449. [CrossRef]

87. Turinawe, A.; Mugisha, J.; Drake, L. Soil and water conservation agriculture in subsistence systems: Determinants of adoption in southwestern Uganda. J. Soil Water Conserv. 2015, 70, 133-142. [CrossRef] 
88. Ward, P.S.; Bell, A.R.; Parkhurst, G.M.; Droppelmann, K.; Mapemba, L. Heterogeneous preferences and the effects of incentives in promoting conservation agriculture in Malawi. Agric. Ecosyst. Environ. 2016, 222, 67-79. [CrossRef]

89. Zhong, H.; Qing, P.; Hu, W. Farmers' willingness to participate in best management practices in Kentucky. J. Environ. Plan. Manag. 2016, 59, 1015-1039. [CrossRef]

90. Ulrich-Schad, J.D.; Babin, N.; Ma, Z.; Prokopy, L.S. Out-of-state, out of mind? Non-operating farmland owners and conservation decision making. Land Use Policy 2016, 54, 602-613. [CrossRef]

91. Läpple, D.; Kelley, H. Understanding the uptake of organic farming: Accounting for heterogeneities among Irish farmers. Ecol. Econ. 2013, 88, 11-19. [CrossRef]

92. Nowak, P. The subversive conservationist. J. Soil Water Conserv. 2009, 64, 113A-115A. [CrossRef]

93. Arbuckle, J.G. Farmer support for extending Conservation Compliance beyond soil erosion: Evidence from Iowa. J. Soil Water Conserv. 2013, 68, 99-109. [CrossRef]

94. Shaffer, S.; Thompson, E., Jr. Encouraging California Specialty Crop Growers to Adopt Environmentally Beneficial Management Practices for Efficient Irrigation and Nutrient Management: Lessons from a Producer Survey and Focus Groups; American Farmland Trust: Washington, DC, USA, 2013; p. 26.

95. McCann, L.; Gedikoglu, H.; Broz, B.; Lory, J.; Massey, R. Effects of observability and complexity on farmers' adoption of environmental practices. J. Environ. Plan. Manag. 2015, 58, 1346-1362. [CrossRef]

96. Varble, S.; Secchi, S.; Druschke, C.G. An examination of growing trends in land tenure and conservation practice adoption: Results from a farmer survey in Iowa. Environ. Manag. 2016, 57, 318-330. [CrossRef] [PubMed]

97. Arbuckle, J.G.; Roesch-McNally, G. Cover crop adoption in Iowa: The role of perceived practice characteristics. J. Soil Water Conserv. 2015, 70, 418-429. [CrossRef]

98. Prokopy, L.S.; Towery, D.; Babin, N. Adoption of Agricultural Conservation Practices: Insights from Research and Practice; Purdue Extension: West Lafayette, IN, USA, 2014.

99. Rolfe, J.; Gregg, D. Factors affecting adoption of improved management practices in the pastoral industry in Great Barrier Reef catchments. J. Environ. Manag. 2015, 157, 182-193. [CrossRef] [PubMed]

100. Vignola, R.; McDaniels, T.L.; Scholz, R.W. Governance structures for ecosystem-based adaptation: Using policy-network analysis to identify key organizations for bridging information across scales and policy areas. Environ. Sci. Policy 2013, 31, 71-84. [CrossRef]

101. Rezvanfar, A.; Samiee, A.; Faham, E. Analysis of factors affecting adoption of sustainable soil conservation practices among wheat growers. World Appl. Sci. J. 2009, 6, 644-651.

102. Lemke, A.; Lindenbaum, T.; Perry, W.; Herbert, M.; Tear, T.; Herkert, J. Effects of outreach on the awareness and adoption of conservation practices by farmers in two agricultural watersheds of the Mackinaw River, Illinois. J. Soil Water Conserv. 2010, 65, 304-315. [CrossRef]

103. Luloff, A.; Finley, J.; Myers, W.; Metcalf, A.; Matarrita, D.; Gordon, J.S.; Raboanarielina, C.; Gruver, J. What Do Stakeholders Add to Identification of Conservation Lands? Soc. Nat. Resour. 2011, 24, 1345-1353. [CrossRef]

104. Kalcic, M.; Prokopy, L.; Frankenberger, J.; Chaubey, I. An in-depth examination of farmers' perceptions of targeting conservation practices. Environ. Manag. 2014, 54, 795-813. [CrossRef] [PubMed]

105. Januchowski-Hartley, S.R.; Moon, K.; Stoeckl, N.; Gray, S. Social factors and private benefits influence landholders' riverine restoration priorities in tropical Australia. J. Environ. Manag. 2012, 110, $20-26$. [CrossRef] [PubMed]

106. Cox, E. Lease-Based Approach to Sustainable Farming, Part II: Farm Tenancy Trends and the Outlook for Sustainability on Rented Land. Drake J. Agric. Law 2011, 16, 5.

107. Druschke, C.; Secchi, S. The impact of gender on agricultural conservation knowledge and attitudes in an Iowa watershed. J. Soil Water Conserv. 2014, 69, 95-106. [CrossRef]

108. Greiner, R.; Patterson, L.; Miller, O. Motivations, risk perceptions and adoption of conservation practices by farmers. Agric. Syst. 2009, 99, 86-104. [CrossRef]

109. Salamon, S.; Farnsworth, R.L.; Bullock, D.G.; Yusuf, R. Family factors affecting adoption of sustainable farming systems. J. Soil Water Conserv. 1997, 52, 265-271.

110. Sheriff, G. Efficient waste? Why farmers over-apply nutrients and the implications for policy design. Appl. Econ. Perspect. Policy 2005, 27, 542-557. [CrossRef] 
111. Brandt, B.; Baird, J. BMP Challenge: Yield and Income Risk Protection for Corn Farmers Who Adopt Water Quality BMPs. 2008. Available online: http:/ / www.dep.state.pa.us/dep/subject/advcoun/ag/2008/ August2008/BMP\%20Challenge\%20PA\%20.pdf (accessed on 2 February 2018).

112. Nyaupane, N.P.; Gillespie, J.M. Louisiana crawfish farmer adoption of best management practices. J. Soil Water Conserv. 2011, 66, 61-70. [CrossRef]

113. Teklewold, H.; Kohlin, G. Risk preferences as determinants of soil conservation decisions in Ethiopia. J. Soil Water Conserv. 2011, 66, 87-96. [CrossRef]

114. Nickerson, C.J.; Borchers, A. US Farmland Tenure Patterns: Overview (PowerPoint), Agricultural Outlook Forum 2011; United States Department of Agriculture: Washington, DC, USA, 2011.

115. Odgaard, M.V.; Moeslund, J.E.; Bøcher, P.K.; Dalgaard, T.; Svenning, J.-C. The relative importance of geophysical constraints, amenity values, and farm-related factors in the dynamics of grassland set-aside. Agric. Ecosyst. Environ. 2013, 164, 286-291. [CrossRef]

116. Ryan, R.L.; Erickson, D.L.; De Young, R. Farmers' motivations for adopting conservation practices along riparian zones in a mid-western agricultural watershed. J. Environ. Plan. Manag. 2003, 46, 19-37. [CrossRef]

117. Perry-Hill, R.; Prokopy, L. Comparing different types of rural landowners: Implications for conservation practice adoption. J. Soil Water Conserv. 2014, 69, 266-278. [CrossRef]

118. Andrews, A.; Clawson, R.; Gramig, B.; Raymond, L. Why do farmers adopt conservation tillage? An experimental investigation of framing effects. J. Soil Water Conserv. 2013, 68, 501-511. [CrossRef]

119. Reimer, A.; Thompson, A.; Prokopy, L.S.; Arbuckle, J.G.; Genskow, K.; Jackson-Smith, D.; Lynne, G.; McCann, L.; Morton, L.W.; Nowak, P. People, place, behavior, and context: A research agenda for expanding our understanding of what motivates farmers' conservation behaviors. J. Soil Water Conserv. 2014, 69, 57A-61A. [CrossRef]

120. Rahelizatovo, N.C.; Gillespie, J.M. Factors influencing the implementation of best management practices in the dairy industry. J. Soil Water Conserv. 2004, 59, 166-175.

121. Pannell, D.J.; Vanclay, F. Changing Land Management: Adoption of New Practices by Rural Landholders; CSIRO Publishing: Collingwood, VIC, Australia, 2011.

122. Alix-Garcia, J.M.; Shapiro, E.N.; Sims, K.R.E. Forest conservation and slippage: Evidence from Mexico's national payments for ecosystem services program. Land Econ. 2012, 88, 613-638. [CrossRef]

123. Parker, D.P.; Thurman, W.N. Crowding out open space: The effects of federal land programs on private land trust conservation. Land Econ. 2011, 87, 202-222. [CrossRef]

124. Wu, J. Slippage effects of the conservation reserve program. Am. J. Agric. Econ. 2000, 82, 979-992. [CrossRef]

125. Pannell, D.J. Social and economic challenges in the development of complex farming systems. Agroforest. Syst. 1999, 45, 395-411. [CrossRef]

126. Rogers, E.M. Diffusion of Innovations; Simon and Schuster: New York, NY, USA, 2010. 